\title{
Investigating FGF11 gene transcription level in cancer cells among colorectal cancer patients
}

\author{
Golshan Khalafian ${ }^{1}, \underline{\text { Maliheh Entezari }}^{2}$, Maryam Bikhof Torbati ${ }^{3}$ \\ ${ }^{1}$ MSc, Department of Genetics, Faculty of Advanced Science and Technology, Tehran Medical Sciences, Islamic Azad \\ University, Tehran, Iran \\ ${ }^{2}$ Associate Professor, Department of Genetics, Faculty of Advanced Science and Technology, Tehran Medical \\ Sciences, Islamic Azad University, Tehran, Iran \\ ${ }^{3}$ Assistant professor, Department of Biology Faculty of Science, Yadegar - e-Imam Khomeini (RAH) Shahre-Rey Branch, \\ Islamic Azad University, Tehran, Iran
}

\begin{abstract}
Background: Colorectal cancer (CRC) is the fourth leading cause of cancer-caused death around the world. Reports of the unnecessary transcription of family genes of the fibroblast growth factor in several types of cancer indicate the role of these factors in tumorgenesis and progression of cancer. Therefore, the level of FGF11 transcription was evaluated in colorectal cancer tumor tissues relative to the normal tissue adjacent to cancer.

Materials and methods: In this study, 30 tumor tissue samples and 30 adjacent tumor tissue samples were collected from patients with colorectal cancer among those referred to Imam Khomeini Hospital. After extracting the entire RNA from the samples and synthesizing cDNA, quantitative real-time PCR method was used to evaluate the level of FGF11 transcription in the mRNA level.

Results: The level of FGF11 transcription in cancer tissues was 1.55 times higher than in non-cancer tissues, but a significant difference was not found between the two healthy and tumor groups $(\mathrm{P}=0.402)$. Increased FGF11 transcription in patients with stages III and IV (high stage) was significantly different from those with stages 0 , I and II (low stage) $(\mathrm{P}=0.057)$. The transcription of this gene did not show a significant relationship with tumor grade $(\mathrm{P}=0.193)$, age $(\mathrm{P}=0.896)$, size of tumor $(\mathrm{P}=0.428)$, and lymphatic invasion $(\mathrm{P}=0.651)$.

Conclusion: Based on the results, increasing the FGF11 transcription in atages III and IV of colorectal cancer than that at stages 0 , I and II may indicate the potential role of this gene in tumorigenesis of colorectal cancer, while further investigations are required in this regard.
\end{abstract}

Keywords: Colorectal cancer, FGF11, Biomarker.

Cited as: Khalafian G, Entezari M, Bikhof Torbati M. Investigating FGF11 gene transcription level in cancer cells among colorectal cancer patients. Medical Science Journal of Islamic Azad University, Tehran Medical Branch 2020; 30(1): 51-58.

Correspondence to: Maliheh Entezari

Tel: +982122006664

E-mail: mentezari@iautmu.ac.ir

ORCID ID: 0000-0003-4191-3351

Received: 3 Dec 2019; Accepted: 16 Apr 2019 
مجله علوم يزشكى دانشخاه آزاد اسلامى

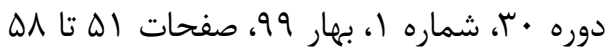

Original

Article

\section{بررسى سطح رونوشت زن FGF11 در سلولهاى سرطانى بيماران مبتلا به سرطان كلور كتال}

\section{كلشن خلفيان'؛ مليحه انتظارى؟، مريم بى خوف تربتى}

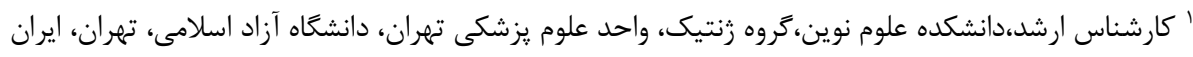

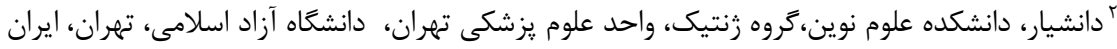

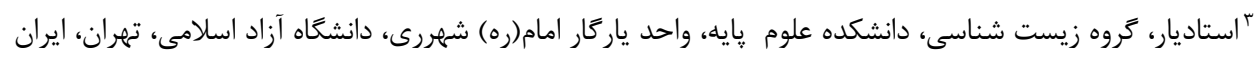

جـكده

سابقه و هدف: سرطان كولوركتال جهارمين علت مركى و مير ناشى /ز سرطان در سراسر جهان /ست. تزارشات مبنى بر رونويسى

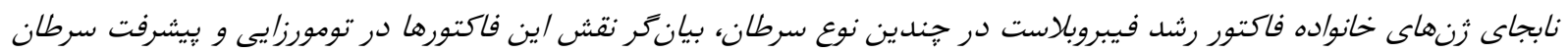

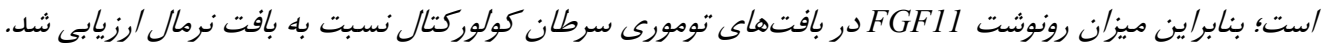

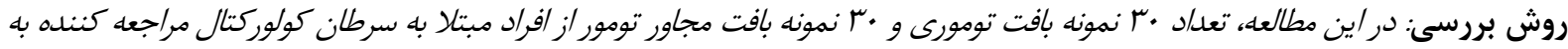

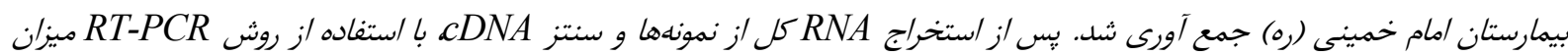
رونوشت FGF11 در سطح

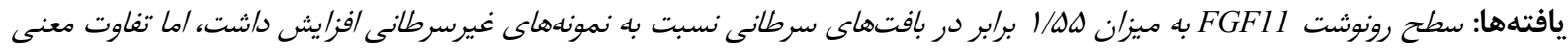

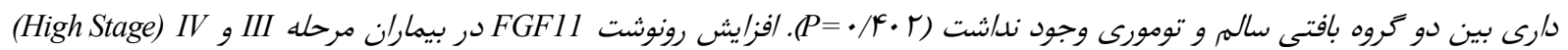

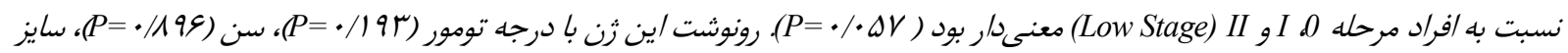

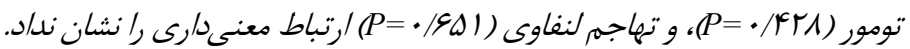

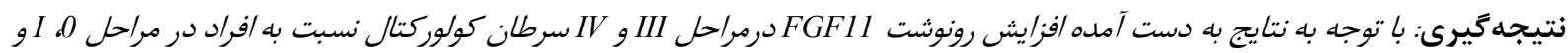

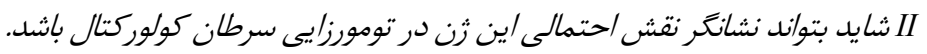

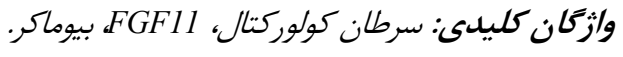

روده بزرى در كل جهان تشخيص داده شده است (Y). برخى داري مقدمه مطالعات نشان دادند كه بروز اين سرطان در كشورهاى توســانه

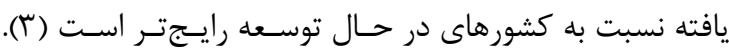

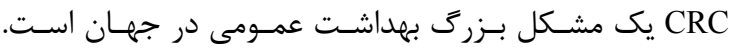

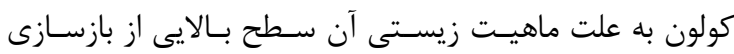

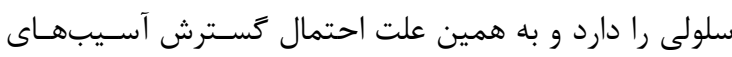

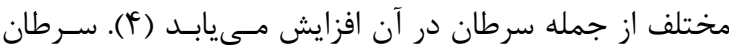

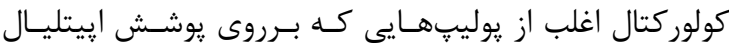

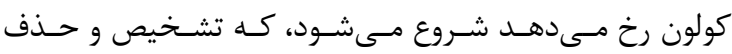

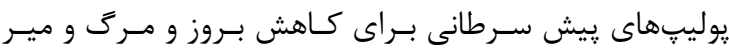

در حال حاضر يكى از شايعترين سرطانهاى دسـتخاه گَكوارش

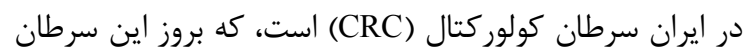

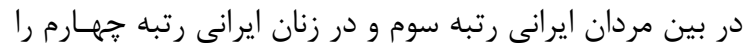

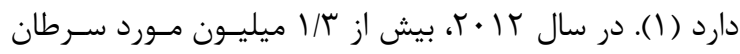

آدرس نويسنده مسئول: تهر ان، دانشكاه آزاد اسلامى، واحد علـوم يزشـكى تهـران، دكتـر مليحهـ انتظـارى (email: : mentezari@iautmu.ac.ir) ORCID ID: 0000-0003-4191-3351 تاريخ دريافت مقاله: 9V/4/Ir تاريخ هذيرش مقاله: 
(homologous factor

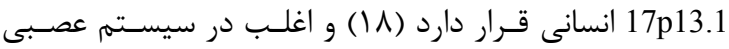

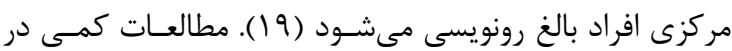
خصوص جگگونكى عملكـرد ايـن زن در دسـترس اسـت. Lee و همكارانش در مطالعات جديدى به نقـش FGF11)

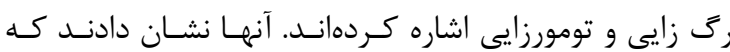

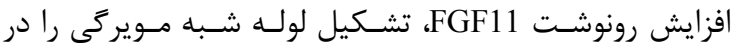
سلولهاى اندوتليال انسانى تحريك مى كند و همجنــين سـطح يروتئينهاى اتصالات محكم را افزايش مى لهدهد (IV). همجنين Ye نادرسـت، سـطح رونوشـت FGF11 در سـلول هــاى تومـورى

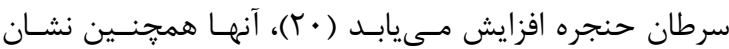

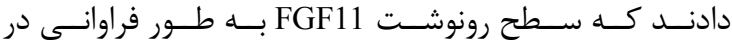
استئو كلاستهاى سلولهاى تومورى غول ييكر افزايش داشـت

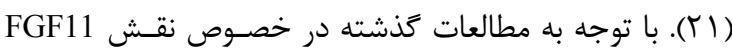
در ييشرفت سرطان، هدف از انجام اين مطالعه بررسـى سـطح رونوشت زن FGF11 در بيماران مبتلا به سـرطان كولوركتـال

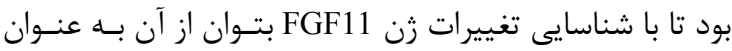
يك نشانگر مولكولى در تشخيص و درمان استفاده كرد.

\section{مواد و روشها}

اين مطالعه بصورت تجربى رِ از تاييد كميته اخلاق دانشـعاه بــه شماره IR.IAU.TMU.REC.1396.226 اجرا شد.

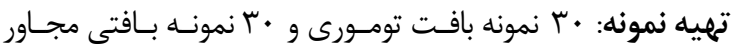
تومور (نرمال) از افراد مبتلا به سـرطان روده بـزرى از بيمارسـتان

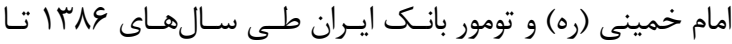

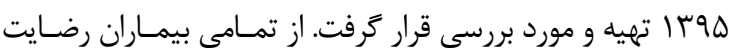

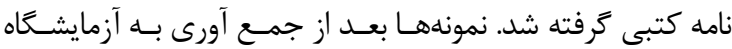

منتقل شده و مراحل استخراج RNA بر روى آنها انجام شد. استخراج RNA و سنتزRNA cDNA كل طبق يروتكـل ( Cat RNeasy Micro Kit (QIAGEN, Germany) (No. /ID74004 ز زمونههاى بافتى استخراج شد. يس از اسـتخراج RNA از نمونـهـ

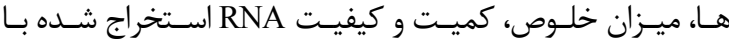

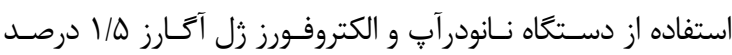

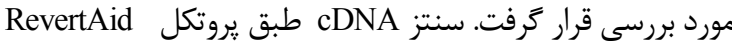
First Strand cDNA Synthesis Kit (Thermo Fisher, USA)

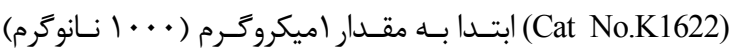

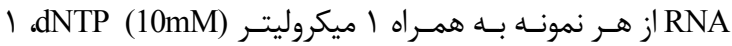

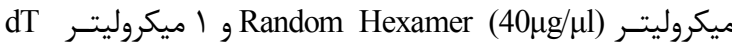

CRC بسيار مهم است (ه). تعداد بسيارى از تغييرات مولكـولى ز جمله جهشهاى زنى و تغييرات إيىزنتيكى كه در شـروع و

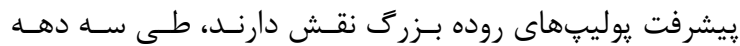
كذشته شناسايى شدهاند، كه ثابت مى كند CRC يـك بيمـارى ناهمخنى است كه عوامل ارثى و محيطى در ايجـاد و ييشـرفت

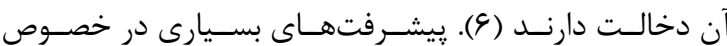
تشخيص و درمان CRC انجـام شـده، امـا هنــوز يـك بيمـارى غيرقابل كنترل است و تهديد بسيار جدى براى افراد است (V).

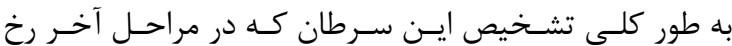
مىدهد اساسا به علت متاستاز سريع آن است، و يكى از موانـع اوليه در دستيابى به درمان موثرتر است (†). تشخيص سـرطان

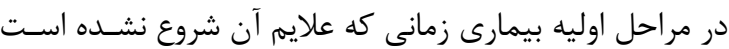
مىتواند منجر به درمان به موقع و بهببود سريعتر بيمارى شـود

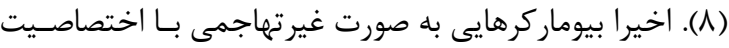

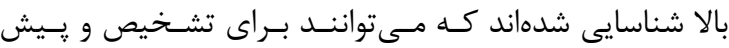
آكَاهى زودهنعَام در بيماران مبتلا به CRC مورد استفاده واقـع شوند (9). يك بيوماركر مىتواند مجموعهاى از تغييرات ماننـد

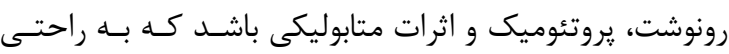

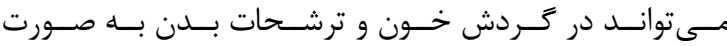
غيرتهاجمى ارزيابى شود ( • (1). فاكتورهـاى رشـد فيبروبلاسـت FGF) Fibroblast Growth Factor

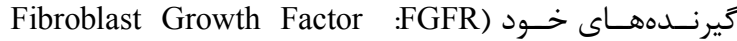
(Receptor

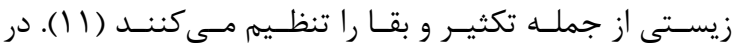

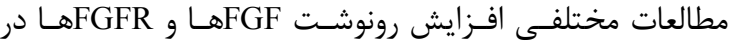

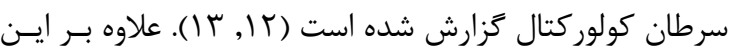
مطالعاتى راجع به نقـش FGFهـا در تكثيرسـلولى، مهــاجرت، تمايز، رگزايى و در واقع تشكيل تومورهاى ريشــفـته در انـواع

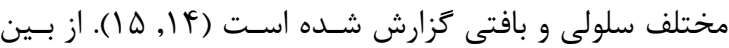

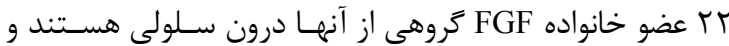
در خانوادهاى جداگانه طبقه بندى مىشوند، به دليـل عملكـرد

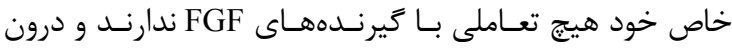

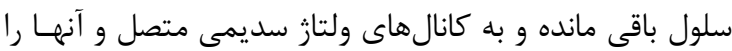

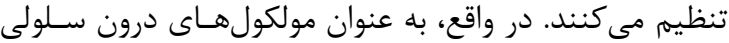
نقش خود را مستقل از FGFRها ايفا مى كنــــ (ع (1). خـانواده

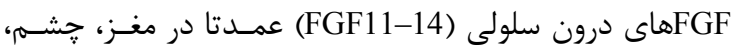

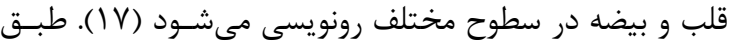
مطالعات فاكتور رشد فيبروبلاست || (FGF11) كه به عنـوان فاكتور رشـد همولـوگ س FHF3 Fibroblast growth factor : 


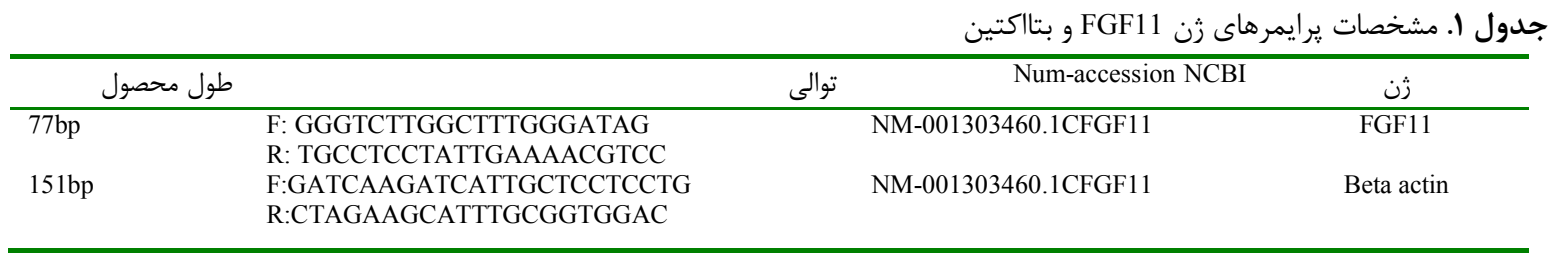

بين دو گروه از آزمون Independent samples t- test اسـتفاده شـد. جهت بررسى ميزان رونوشت نسـبى ثن مـورد مطالعـه از نـرم افـزار

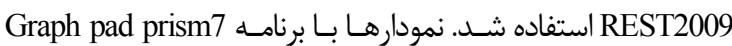
رسم شد و P كمتر از ه • • • معنى دار در نظر گرفته شد.

\section{يافتهها}

به منظور بررسـى اختصاصـيت يرايمرهـا و اطمينـان از تكثيـر اختصاصى زنهــاى مـورد مطالعـه در محصـول PCR، نمـودار منحنى ذوب (نمودارهاى ا و ؟) بصورت جداگانه براى زنهاى B-actin و FGF11 توسط دستخاه به صورت تك قله رسم شـد

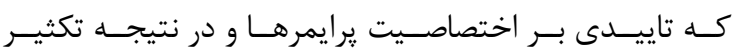
اختصاصى قطعات زنهاى FGF11 و B-actin است.
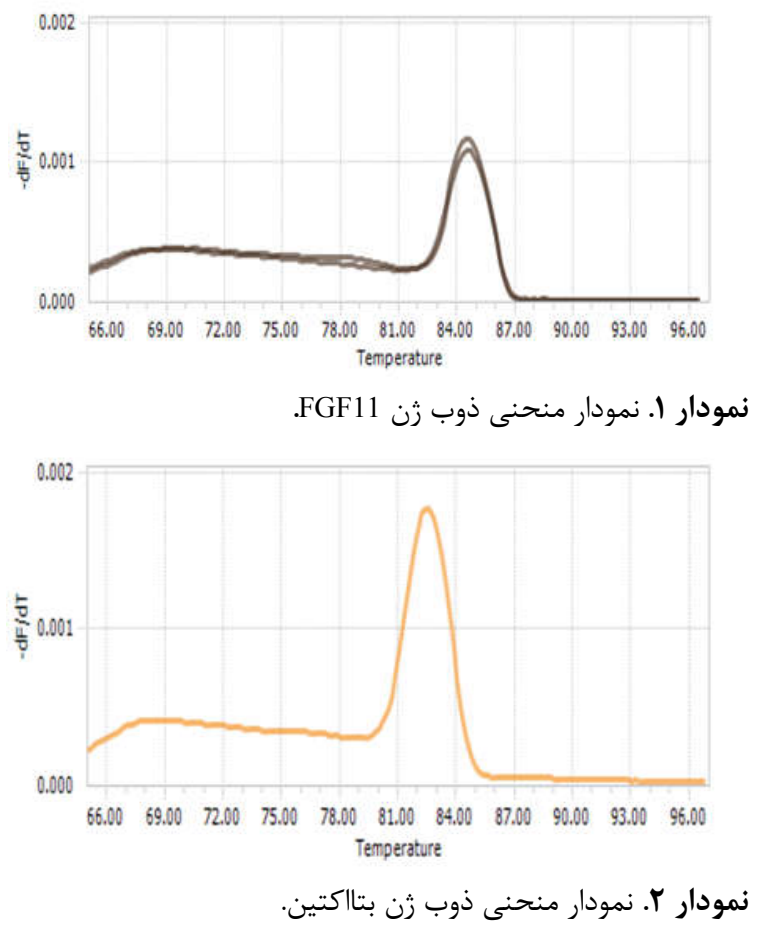

همان طور كه در نمودار r مشاهده مىشود، رونوشت زن FGF11

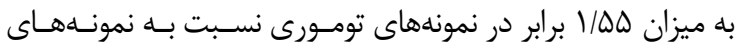

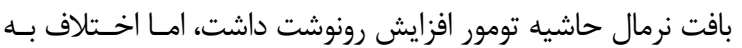

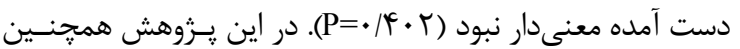

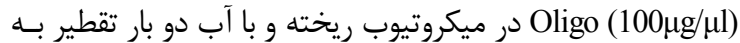
حجم • ا ميكروليتر رسانده شد، سيس به هر نمونسه ا ميكروليتـر

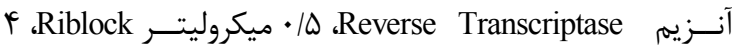
ميكروليتر بافر DX اضافه كرده و در نهايت با آب بــه حجـم نهـايى • · ميكروليتر رسانده شد. واكنش طبق شرايط دمـايى هادرجـهـ،

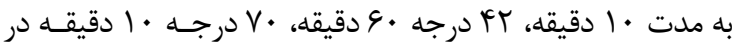
دستخاه ترموسايكلر مدل BEK Lab انجام شد. براى بررسـى عـدم

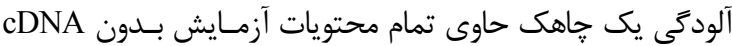

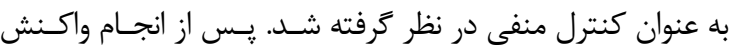

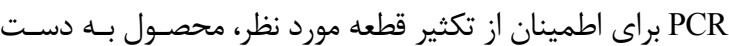

$$
\text { آمده روى زل آكارز الكتروفورز شد. }
$$

Real time PCR

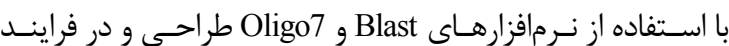
PCR

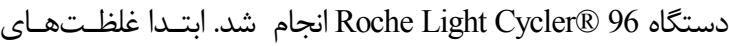

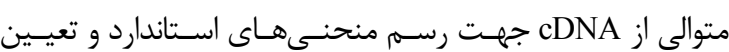
كارآمدى PCR براى زن مورد نظر تهيه شد. واكنش طبق يروتكـل SYBR green master mix (Takara, Japan) (Cat No. انجام شد. هر واكنش در حجم نهـايى ه HRR820Q)

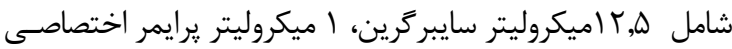

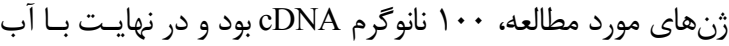

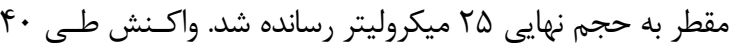

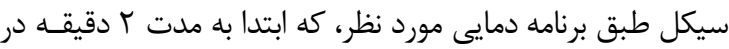

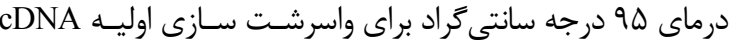

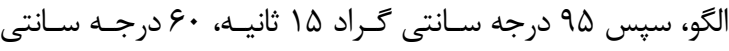

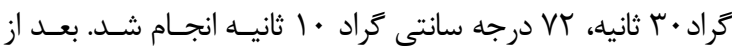

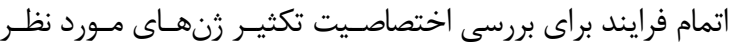
منحنىهاى ذوب رسم شده مورد بررسى قرار گرفت. از آنجايى كه

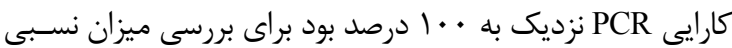

رونوشت از روش ليواك استفاده شد. تحليل آمارى: بـا اسـتفاده از نــرم افـزار SPSSv23 ابتــدا از طريـق

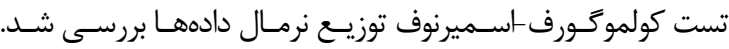

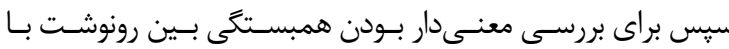
فاكتورهاى كلينيكوياتولوزى تست ييرسون و براى مقايسـه ميـانخين 
طبق آزمون t-test ميانكين رونوشت FGF11 در كروههاى

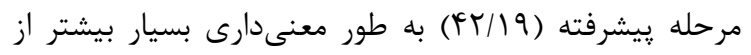

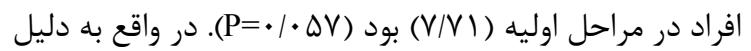
اينكه زن FGF11 در مراحل קيشرفته، سطح رونويسى قابل

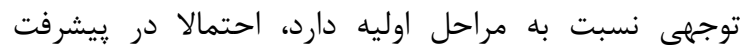
سرطان كولوركتال نقش موثرى دارد.

\section{بحث}

بروز و ميزان مـرى و ميـر سـرطان كولور كتـال در كشـورهاى توسعه يافته به دليل تشخيص زود هنكام سرطان

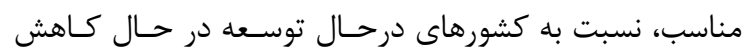

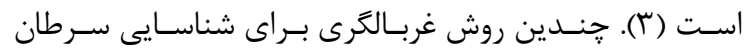

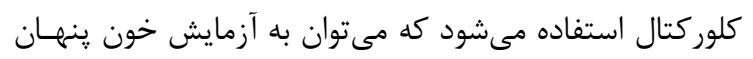

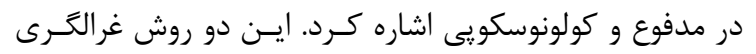

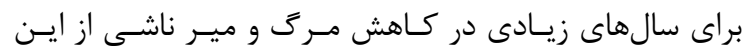

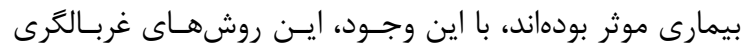

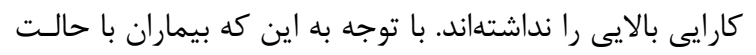

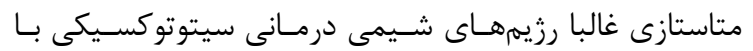

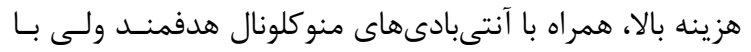

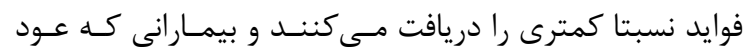

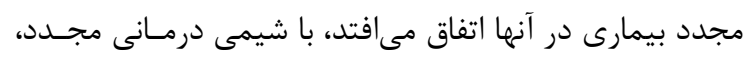

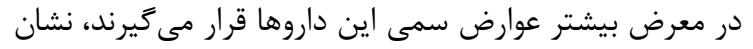

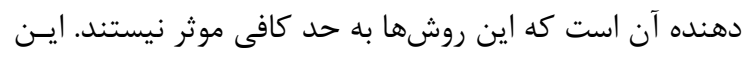

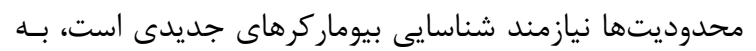
ويزه بيوماركرهايى در سرم يا پِلاسـما، بـراى تشـخيص، هـيش

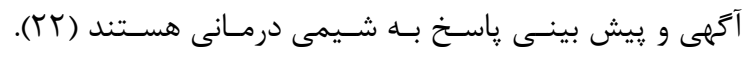

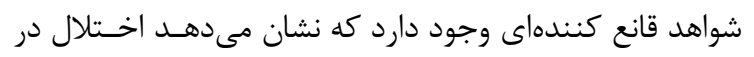
مسير קيام رسانى FGF در بروز بسيارى از سرطانها نقش دارد

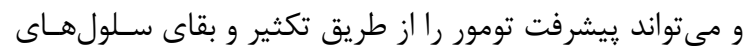

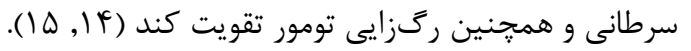

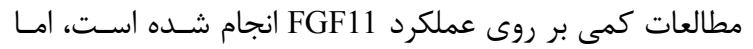

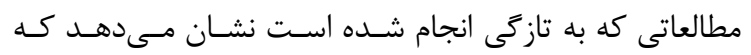

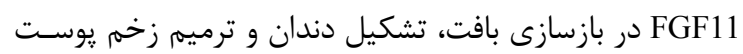

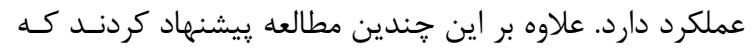

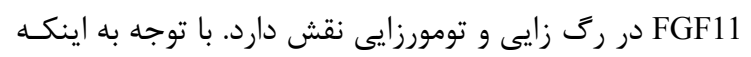
القاى هييوكسى FGF11 به FIF-1

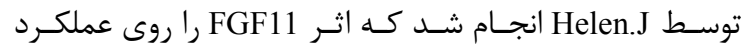

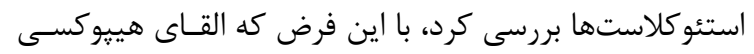

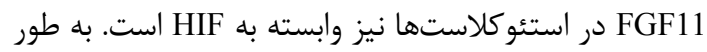

ارتباط بين رونوشت FGF11 و شـاخصهـاى كلينيكويـاتولوزى بـاــا

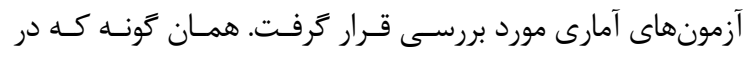

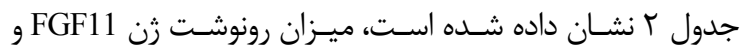

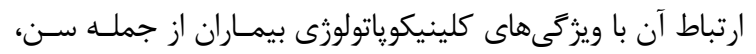

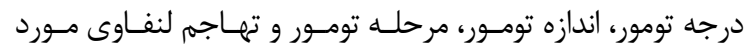

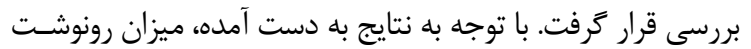

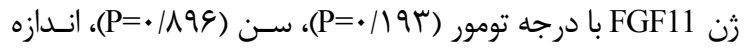

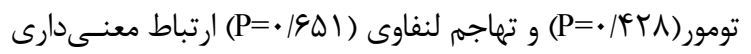

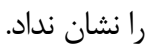

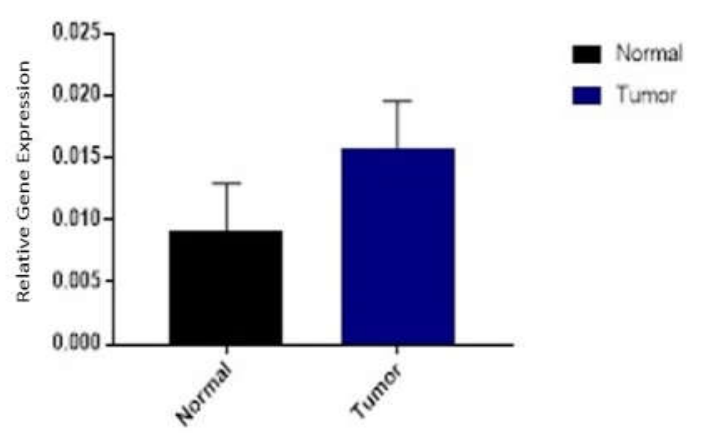

نمودار rا. مقايسه ميزان نسبى رونوشت FGF11 بافت توهورى بـاـا بافت سالم مجاور تومور در بيماران مبتلا به سرطان كولوركتال

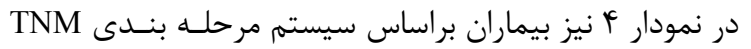

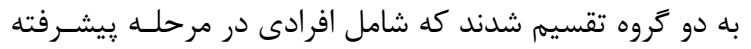

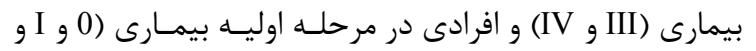
(II

Expression of FGF11

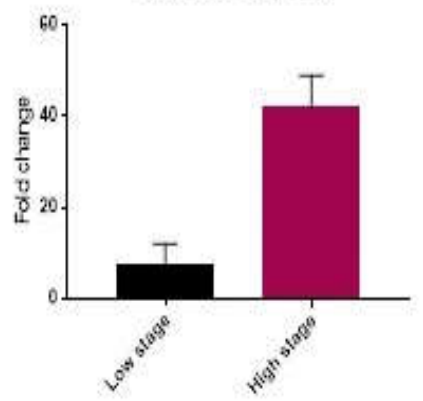

Lou stage (Stage 0, (I) - High stage (Stage lli.iN)

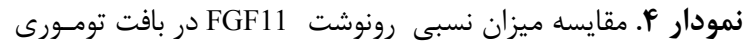

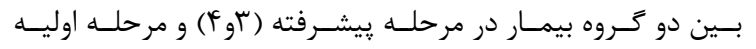

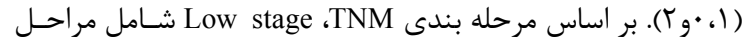

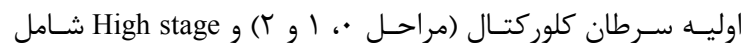

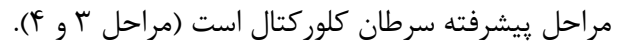


جدول r. ارتباط ميان سطح رونوشت زن FGF11 با ويزگى هاى كلينيكوياتولوزى بيماران مبتلا به سرطان كولوركتال"

\begin{tabular}{|c|c|c|c|}
\hline P-value & ميزان رونوشت FGF11 & تعداد بيماران n (.) & متغيرها \\
\hline \multirow[t]{3}{*}{$\cdot / 199$} & & & سن بيماران بر حسب سال \\
\hline & $f / r q$ & $V(T r / T \%)$ & $\leq \Delta$ \\
\hline & $1 N / T$. & r & $>\Delta$. \\
\hline \multirow[t]{6}{*}{$\cdot / \wedge 9 \Delta$} & & & مرحله بندى تومور \\
\hline & r/A & $q(r \cdot \%)$ & 0 \\
\hline & D/GT & $V(r r / r \%)$ & $\begin{array}{l}\text { I } \\
\text { II }\end{array}$ \\
\hline & $|r / 9|$ & $\Lambda(\Gamma \& / V \%)$ & III \\
\hline & FA/VT & $\Delta(\mid \varepsilon / V \%)$ & IV \\
\hline & $9 / \Delta F$ & $1(\Gamma / \Gamma \%)$ & \\
\hline \multirow[t]{5}{*}{.1194} & & & درجه تومور \\
\hline & $r q|\Lambda|$ & $9(r \cdot \%)$ & I \\
\hline & IT/TY & $1 \cdot(r / \pi \%)$ & $\begin{aligned} \text { II } \\
\text { III }\end{aligned}$ \\
\hline & $|r / 1|$ & $r(1 \cdot \%)$ & IV \\
\hline & r/9 & $\Lambda(Y G / V \%)$ & \\
\hline \multirow[t]{3}{*}{$\cdot /$ EYA } & & & اندازه تومور ( بر حسب سانتى متر) \\
\hline & $19 / 49$ & r $(V \& \mid \varphi \%)$ & $\leq \Delta$ \\
\hline & $\Lambda / Y \Lambda$ & $V(T r / T \%)$ & $>\Delta$ \\
\hline \multirow[t]{4}{*}{$\cdot|9 \Delta|$} & & & تهاجم لنفاوى \\
\hline & $1 r / 09$ & r $(V \& \mid \& \%)$ & بلى \\
\hline & $19 / 9 V$ & $f(\mid r / r \%)$ & خير \\
\hline & & $r(1 \cdot \%)$ & نامشخص \\
\hline
\end{tabular}

شـبكه مـويرگى در سـلولهــاى انـدوتليال انسـانى را تحريـك

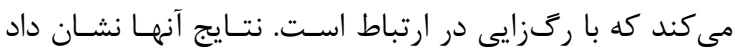

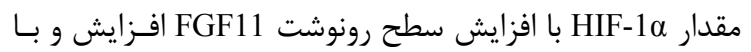
خاموش سازى FGF11 كاهش يافته بـود كـهـ حــــ اكى از نقـش تنظيمى FGF11 در توليد يا كاهش HIF-1

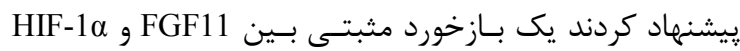
وجـود دارد كـهـ FGF11 بــا FIF-10 در تعامــل اسـت. بــدين

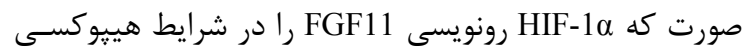
القا مى كند و در مقابل مقدار HIF-1

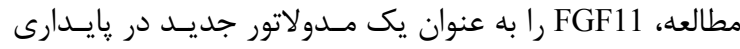

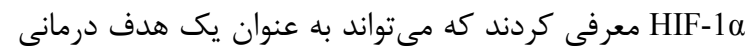

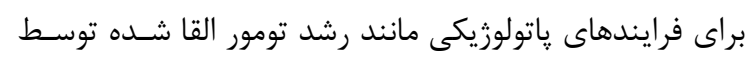

$$
\text { هييوكسى باشد (IV) }
$$

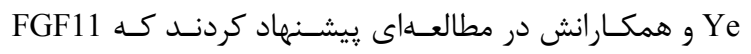
هدف مستقيم miR-24-3p است، به دليل اينكه با عدم فعاليت سطح رونويسى miR-24-3p

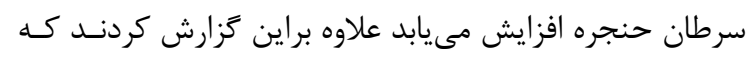

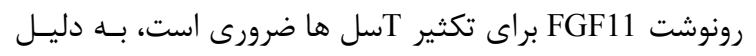

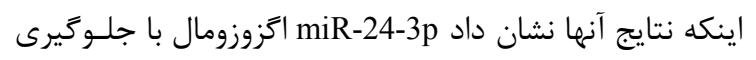

كلى افزايش فعاليت استئوكلاستها مستقيما منجر به تخريسب استخوان در شرايطى مثل آرتريت روماتوئيد يا متاستاز سرطان

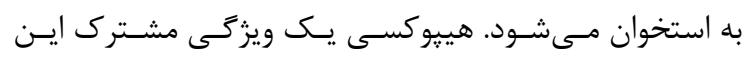

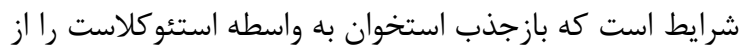

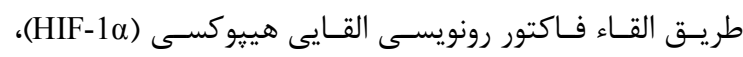

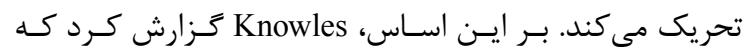

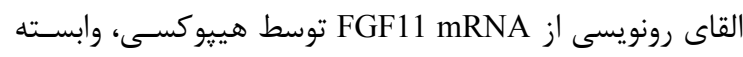

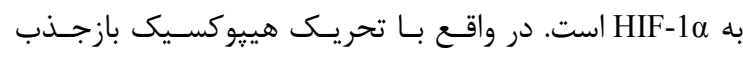

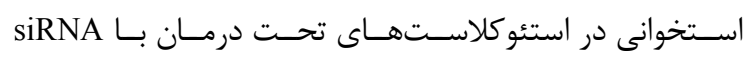
اختصاصى FGF11 مهار شده بود و باعث كـاهش ترشـح ايسن فاكتور شد. همجنين كزارش كرد FGF11 در استئوكلاسـتهاى تومورى سلولى غول پييكر استخوان افـزايش رونوشـت داشـت.

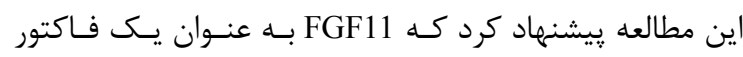

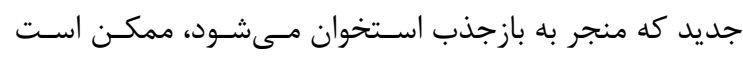

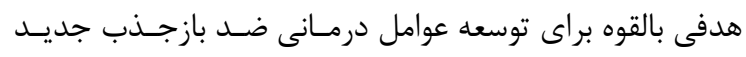

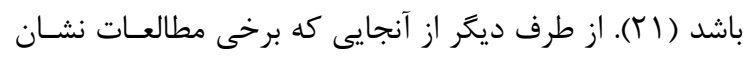

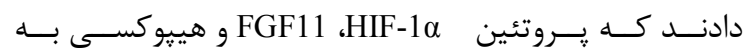

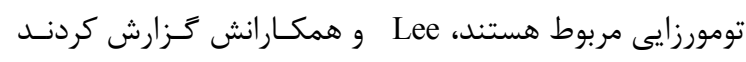
FGF11 توسط HIF-1 تحت هييوكسى، القا شـده و تشـكيل 
متاستاز نقش داشـته باشـد. همجنــين در مطالعـه حاضـر كـهـ

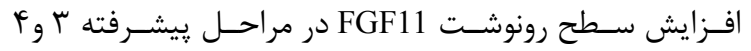

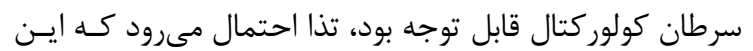
زن در مرحله يِيشرفته بيمارى نقش مهمى داشته باشد.

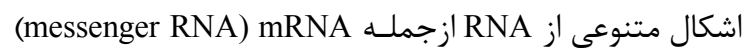

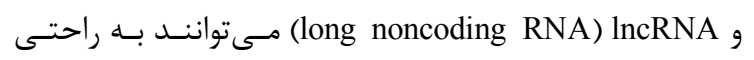
استخراج، ذخيره و در مايعات مختلف بدن مـورد مطالعـه قـرار

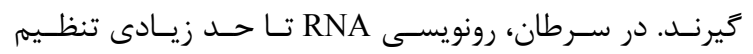

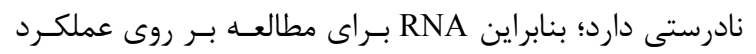
سلولهاى سرطانى كزينه خوبى است. برخى مطالعات زنهايى

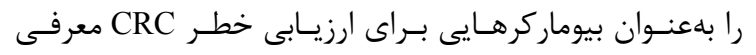

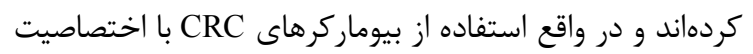
بالا در مراحل مختلـف توسـعه بيمـارى مسىتوانــد جـايكزين

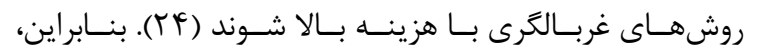
شناسايى بيوماركرهاى جديد و مفيدى كه بتوانند با مشخصات

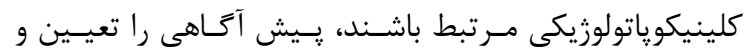

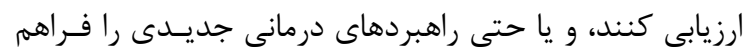
كنند، ضرورى است.

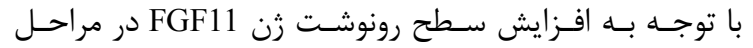

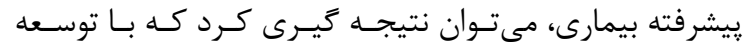

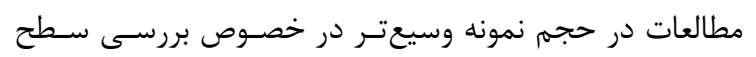

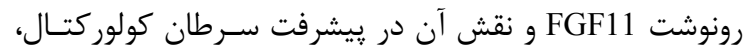

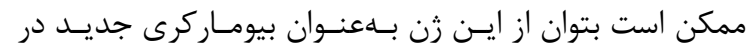
تشخيص مراحل ييشرفت سرطان كلوركتال استفاده كرد.

\section{تشكر و قدردانى}

مطالعه حاضر حاصل طرح تحقيقاتى دوره كارشناسى ارشد رشته زنتيك مولكولى خانم كلشن خلفيان است. از همكارى بخش ياتولوزى بيمارستان امام خمينى همكارى در اين تحقيق صميمانه تشكر و قدردانى مى كنيه.
از تكثير Tسلها از طريق سـركوب FGF11 در يـاتوزنز تومـور

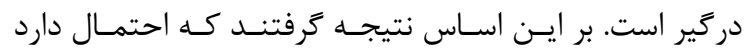

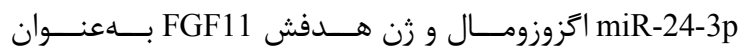
بيوماركر ييش آكاهى بالينى براى بيماران NPC معرفـى شـود

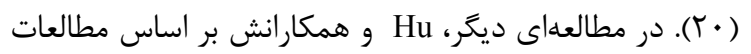

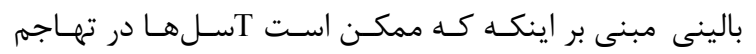

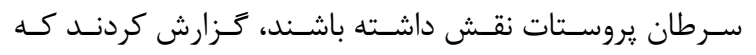

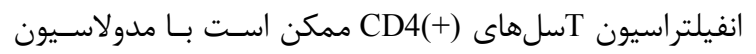

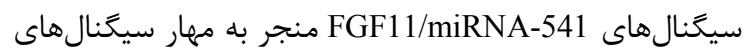
كيرنده آندروزن سرطان يروستات شوند و در نهايـت بـا تغييـر

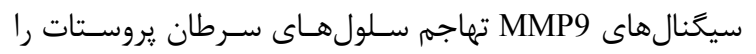
تقويت كنند. علاوه بر اين آنهـا بـراى اثبـات نقـش FGF11 در تقويـت سـلولهـاىT در متاسـتاز ســرطان يروسـتات، ميـزان

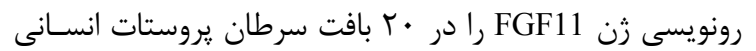

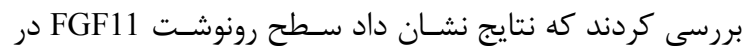
بافت تومورى نسبت به بافت نرمال حاشيهى تومـور بـالاتر بـود

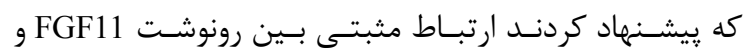

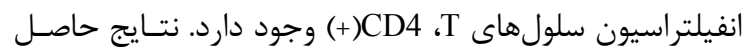

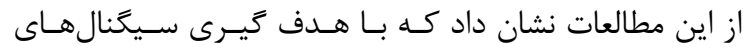
FGF11/ miRNA-541/(AR) androgen receptor /MMP-9 ممكن است رويكرد درمانى بالقوهى جديدى براى مقابله بهتـر

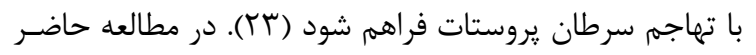

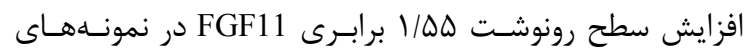

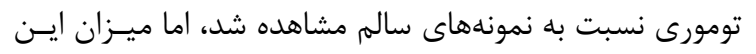

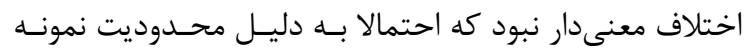

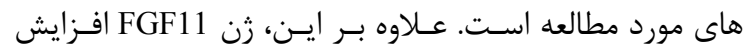

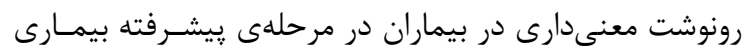

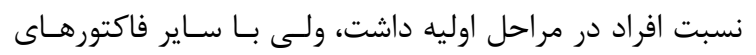

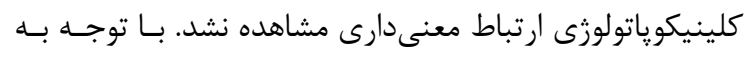

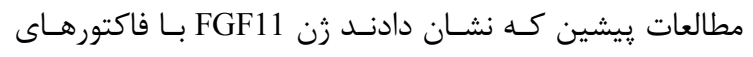

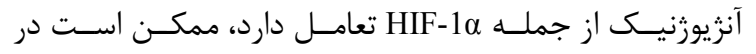

\section{REFERENCES}

1. Fakheri H, Janbabai G, Bari Z, Eshqi F. The epidemiologic and clinical-pathologic characteristics of colorectal cancers from 1999 to 2007 in Sari, Iran. Journal of Mazandaran University of Medical Sciences 2008; 18:58-66. [In Persian]

2. Lam K, Pan K, Linnekamp JF, Medema JP, Kandimalla R. DNA methylation based biomarkers in colorectal cancer: a systematic review. Biochim Biophys Acta 2016;1866:106-20.

3. Rahimi Pordanjani S, Baeradeh N, Lotfi MH, Pourmohammadi B. Epidemiology of colorectal cancer: incidence, mortality, survival rates and risk factors. Razi J Med Sci 2016;23:41-50.

4. Arvelo F, Sojo F, Cotte C. Biology of colorectal cancer. Ecancermedicalscience 2015;9:520.

5. Benson AB, Venook AP, Cederquist L, Chan E, Chen Y-J, Cooper HS, et al. Colon cancer, version 1.2017, NCCN clinical practice guidelines in oncology. J Natl Compr Canc Netw 2017;15:370-98. 
6. Grady WM, Markowitz SD. The molecular pathogenesis of colorectal cancer and its potential application to colorectal cancer screening. Dig Dis Sci 2015;60:762-72.

7. Nedaeinia R, Sharifi M, Avan A, Kazemi M, Nabinejad A, Ferns GA, et al. Inhibition of microRNA-21 via locked nucleic acid-anti-miR suppressed metastatic features of colorectal cancer cells through modulation of programmed cell death 4. Tumor Biol 2017;39:1010428317692261.

8. Saebnia N, Sadeghizadeh M, Movahedi Motlagh F, Esmatabadi D, Javad M. A Review of Genes, Markers, and Methods in Predicting Colon Cancer Recurrence. J Police Med 2017;5:389-402.

9. Siravegna G, Bardelli A. Blood circulating tumor DNA for non-invasive genotyping of colon cancer patients. Mol Oncol 2016;10:475-80.

10. Henry NL, Hayes DF. Cancer biomarkers. Mol Oncol 2012;6:140-6.

11. Yun Y-R, Won JE, Jeon E, Lee S, Kang W, Jo H, et al. Fibroblast growth factors: biology, function, and application for tissue regeneration. J Tissue Eng 2010;1:218142.

12. Sato T, Oshima T, Yoshihara K, Yamamoto N, Yamada R, Nagano Y, et al. Overexpression of the fibroblast growth factor receptor-1 gene correlates with liver metastasis in colorectal cancer. Oncol Reports 2009;21:211-6.

13. Jang J-H. Reciprocal relationship in gene expression between FGFR1 and FGFR3: implication for tumorigenesis. Oncogene 2005;24:945.

14. Hossain WA, Morest D. Fibroblast growth factors (FGF-1, FGF-2) promote migration and neurite growth of mouse cochlear ganglion cells in vitro: immunohistochemistry and antibody perturbation. J. Neurosci Res 2000;62:40-55.

15. Kottakis F, Polytarchou C, Foltopoulou P, Sanidas I, Kampranis SC, Tsichlis PN. FGF-2 regulates cell proliferation, migration, and angiogenesis through an NDY1/KDM2B-miR-101-EZH2 pathway. Mol Cell 2011;43:285-98.

16. Hennessey JA, Wei EQ, Pitt GS. Fibroblast growth factor homologous factors modulate cardiac calcium channels. Circ Res 2013; 113:301215.

17. Lee KW, Yim HS, Shin J, Lee C, Lee JH, Jeong JY. FGF11 induced by hypoxia interacts with HIF-1 $\alpha$ and enhances its stability. FEBS letters 2017;591:348-57.

18. Verdier A-S, Mattei M-G, Lovec H, Hartung H, Goldfarb M, Birnbaum D, et al. Chromosomal mapping of two novel human FGF genes, FGF11andFGF12. Genomics 1997;40:151-4.

19. Goetz R, Dover K, Laezza F, Shtraizent N, Huang X, Tchetchik D, et al. Crystal structure of a fibroblast growth factor homologous factor (FHF) defines a conserved surface on FHFs for binding and modulation of voltage-gated sodium channels. J Biol Chem 2009;284:17883-96.

20. Ye SB, Zhang H, Cai TT, Liu YN, Ni JJ, He J, et al. Exosomal miR-24-3p impedes T-cell function by targeting FGF11 and serves as a potential prognostic biomarker for nasopharyngeal carcinoma. J Pathol 2016;240:329-40.

21. Knowles HJ. Hypoxia-induced fibroblast growth factor 11 stimulates osteoclast-mediated resorption of bone. Calcif Tissue Int 2017;100:382-91.

22. Toiyama Y, Takahashi M, Hur K, Nagasaka T, Tanaka K, Inoue Y, et al. Serum miR-21 as a diagnostic and prognostic biomarker in colorectal cancer. J Natl Cancer Inst 2013;105:849-59.

23. Hu S, Li L, Yeh S, Cui Y, Li X, Chang H-C, et al. Infiltrating T cells promote prostate cancer metastasis via modulation of FGF11 $\rightarrow$ miRNA-541 $\rightarrow$ androgen receptor $(\mathrm{AR}) \rightarrow$ MMP9 signaling. Mol Oncol 2015;9:44-57.

24. Nguyen MT, Weinberg DS. Biomarkers in colorectal cancer screening. J Natl Compr Canc Netw 2016;14:1033-40. 